\title{
Role of regulatory $T$ cells in rheumatoid arthritis: facts and hypothesis
}

\author{
Alessia Alunno • Elena Bartoloni • Giuseppe Nocentini • \\ Onelia Bistoni • Simona Ronchetti • Maria Grazia Petrillo • \\ Carlo Riccardi • Roberto Gerli
}

Received: 01 April 2010 / Accepted: 06 April 2010

(C) Springer-Verlag 2010

\begin{abstract}
Regulatory $\mathrm{T}$ cells (Treg) are a CD4+ lymphocyte subset involved in self-tolerance and autoimmunity prevention. There is evidence for a phenotypic and/or functional impairment of this cell subset during the natural history of several chronic autoimmune/inflammatory diseases, including rheumatoid arthritis (RA). Although the intracellular transcription factor FoxP3 is thought to be the master regulator of Treg cell function, a number of other molecules expressed on the cell surface have been proposed for the identification of Treg cells. This is important in order to favour their possible selective isolation and in the development of new therapeutic strategies. In the present paper, available data on phenotypic and functional characterization of Treg cells in both peripheral blood and synovial fluid from RA patients are reviewed and their possible pathogenic role in triggering and perpetuating rheumatoid joint inflammation is discussed.
\end{abstract}

Keywords Treg cells · Rheumatoid arthritis · FoxP3 · GITR

\footnotetext{
A. Alunno · E. Bartoloni · O. Bistoni · R. Gerli (凶) Rheumatology Unit,

Department of Clinical and Experimental Medicine, University of Perugia,

via E. dal Pozzo, Perugia, I-06122, Italy

Tel.: +39-075-5783975

Fax: +39-075-5783105

Email: gerlir@unipg.it

G. Nocentini $\cdot$ S. Ronchetti $\cdot$ M.G. Petrillo $~ \cdot$ C. Riccardi Section of Pharmacology,

Toxicology and Chemotherapy,

Department of Clinical and Experimental Medicine,

University of Perugia, I-06122 Perugia, Italy
}

\section{Introduction}

Regulatory $\mathrm{T}$ (Treg) cells are a specialized CD4+ lymphocyte subset able to modulate immune response to environmental pathogens as well as to prevent immune responses against inappropriate targets, including self antigens [1]. In fact, Treg cells can suppress autoreactive lymphocyte clones that have escaped the negative selection in the thymus by different mechanisms, thus preventing the activation and expansion of these effector cell subsets. Suppression can be either in a cell-cell contact manner or via soluble factors produced by Treg cells themselves [2, 3].

The well-known role played by T cells in the development of autoimmunity was characterized in the mid1990s by Sakaguchi et al. who demonstrated that a T-cell subset expressing high levels of IL- 2 receptor $\alpha$-chains (CD25) was able to prevent the onset of systemic autoimmune diseases in thymectomized mice [4]. The high surface expression of the CD25 molecule, in association with the intracellular expression of the forkhead wingedhelix transcription factor Foxp3 (forkhead fox p3), allows isolation of Treg cells also in human peripheral blood (PB) and the definition of Treg cells as $\mathrm{CD} 4{ }^{+} \mathrm{CD} 25^{\text {high }}$ FoxP $3{ }^{+}$has therefore been considered one of their main phenotypic features [5].

The hypothesis that Treg cells could be involved in the pathogenesis of autoimmune diseases led to subsequent investigations not only in animal models with autoimmune disorders, but also in patients with such diseases in order to clarify the degree to which the Treg cells might be functionally impaired [6, 7].

With regard to their origin, Treg cells can be divided into two main populations with similar phenotypes but 
different developments. Natural Treg cells are generated in the thymus in the early years of life and show the ability to bind self antigens by their T-cell receptor. They are distinguished from adaptive Treg cells that are induced in the PB throughout life by conversion of $\mathrm{CD} 4{ }^{+} \mathrm{CD} 25^{-}$ naive $\mathrm{T}$ cells in the presence of a particular cytokine microenvironment [8-10].

Although Treg cells could be considered a simple population of suppressor $\mathrm{T}$ cells, it has been shown that they are more heterogeneous and play a pivotal role in the maintenance of immune tolerance. They can exert their suppressive activity via different mechanisms in order to eliminate autoreactive effector lymphocyte clones. In particular conditions which allow cell-cell contact, Treg cells are able to trigger apoptotic pathways that lead to the death of effector cells. On the other hand, they secrete soluble molecules such as IL-10 and TGF- $\beta$ which restore an antiinflammatory milieu and thus block the stimuli for effector cells.

Although Treg cells were identified in early studies by their surface expression of CD4 and high levels of CD25, additional surface molecules have subsequently been proposed as specific Treg cell markers, including cytotoxic T lymphocyte antigen-4 (CTLA-4), CD127 and glucocorticoid-induced TNF receptor-related protein (GITR) [11, 12]. GITR is a well-known marker of Treg cells in mice, but little is known about its role in humans. Unfortunately, the fact that CD25, CTLA-4, and GITR are also upregulated on the surface of activated $\mathrm{T}$ cells makes the interpretation of some experimental data difficult in healthy subjects as well as in patients. The discovery of Foxp3 as master regulator for Treg cells added a key marker for this T-cell subset. Foxp3, previously called JM2, was first characterized as the target gene mutated in a murine autoimmune syndrome (X-linked autoimmunity-allergic dysregulation syndrome) and was subsequently related to the human counterpart of this syndrome (immunodysregulation polyendocrinopathy enteropathy X-linked syndrome) [13, 14].

Further studies following Treg cell isolation have shown that this transcription factor is constitutively expressed at high levels in both natural and adaptive $\mathrm{CD} 4{ }^{+} \mathrm{CD} 25^{\text {high }}$ Treg cells in humans and mice. Foxp 3 is required for the natural Treg cell lineage commitment in the thymus and it is essential in stabilizing and amplifying a Treg cell program, inclusive of anergy and defective IL-2 production, induced by interaction of Treg cell precursors with stromal cells in the thymus [14, 15]. Furthermore, recent investigations on induced Foxp3 expression in activated $\mathrm{CD} 4^{+} \mathrm{CD} 25^{-} \mathrm{T}$ cells have shown that the presence of Foxp3 at high levels as well as the persistence of its expression are fundamental for maintaining suppressor function $[15,16]$. Interestingly, it is now well accepted that Foxp3, despite being a distinctive marker for Treg cells, can also be expressed by human effector T cells after activation [17]. However, its expression on $\mathrm{T}$ cells is transient, occasional, and never as high as in Treg cells. An intriguing finding is that FoxP3-positive T-cell populations with absent, or at least low, surface expression of CD25 (CD25-/low), are able to exert an in vitro suppressive activity towards effector $\mathrm{T}$ cells, thereby displaying a regulatory function [18]. Such a cell subset seems to be increased in patients with autoimmune diseases such as systemic lupus erythematosus compared to normal controls, but no data have been published so far on rheumatoid arthritis (RA) [19].

Further studies are required to better characterize its phenotypic and functional features. In this setting, our group is assessing the functional activity of $\mathrm{CD} 25^{-/ \text {low }}$ cells expressing FoxP3 as well as high levels of GITR on the cell surface. The aim of our study was to better characterize this supposed regulatory $\mathrm{CD} 25^{-/ \text {low }}$ subset and to investigate the possible role of GITR as a specific marker of Treg cells also in humans, as mentioned above.

\section{The paradox of Treg cell expansion in RA patients}

The hypothesis that Treg cells may play a key role in the pathogenesis of autoimmune diseases has been tested by several groups. Plenty of data have been published on Treg cell numbers and function in different human chronic inflammatory diseases [20-26]. RA is a systemic inflammatory disorder characterized by chronic synovial inflammation resulting in cartilage and bone damage eventually leading to joint destruction. The aetiology and pathogenesis of RA are not fully understood, although breakdown of self-tolerance is a hallmark of the disease. Several studies have been carried out with the aim of clarifying whether Treg cell dysregulation could be involved as a disease trigger and/or in maintenance of the disease, and in an attempt to shed some light on possible underlying mechanisms by which this dysregulation occurs. Early evidence came from studies performed on murine models of inflammatory arthritis, such as collagen-induced arthritis (CIA) [27]. It has been shown that mice depleted of $\mathrm{CD} 4{ }^{+} \mathrm{CD} 25^{+}$cells develop a more severe arthritis and higher titres of anticollagen antibodies [28]. On the other hand, a single transfer of $\mathrm{CD} 4{ }^{+} \mathrm{CD} 25^{+}$Treg cells into mice exhibiting arthritis symptoms is able to markedly slow disease progression [29]. Moreover, the above-mentioned marker of murine Treg cells, GITR, has been shown to be involved in the development of CIA, as demonstrated by a reduced susceptibility to CIA of GITR-deficient mice [30]. The abolition of GITR signalling in effector $\mathrm{T}$ cells is able to 
reduce the severity of arthritis because of the lack of activation stimuli triggered by this pathway [30].

Initial studies performed in RA patients investigated Treg cell phenotype in PB and synovial fluid (SF) with the aim of also evaluating possible imbalance of Treg cell number in human chronic inflammatory diseases [31, 32]. As summarized in Table 1, conflicting data have been published so far regarding the percentages $\mathrm{CD} 4{ }^{+} \mathrm{CD} 25^{+}$cells in the PB of RA patients [33-37, 40, 41]. On the contrary, there is general agreement that $\mathrm{CD}^{+} \mathrm{CD} 25^{+}$cells are increased in the SF of RA patients [33-37, 40, 41]. Although the entire $\mathrm{CD} 4{ }^{+} \mathrm{CD} 25^{+}$cell population could include variable amounts of effector $\mathrm{T}$ cells expressing CD25 at low levels, these studies also demonstrated an expansion of the CD25 high cell subset in the SF of RA patients, and this subset is thought to include most of the cells with Treg function. However, since the phenotypic characterization of Treg cells by flow cytometry is dependent on the gating set by the operator, the CD25 $5^{\text {high }}$ cell population identified in each of these studies may not correspond, but such a technical issue seems to significantly affect the results only when there are small variations in the percentage of Treg cells. This appears to be supported by both the conflicting data in the PB of RA patients and the homogeneous findings in the SF of RA patients.

Interestingly, Lawson et al. determined the percentage of Treg cell in the PB of selected patients with early RA, naive to any pharmacological therapy, and found a reduction of the PB CD4 ${ }^{+} \mathrm{CD} 25^{+}$Treg cell population. This evidence supports the idea that a deficiency of this cell subset may be a possible factor in susceptibility to RA [42]. This hypothesis seems to be further supported by investigations of the correlation between the percentage of Treg cells in PB and disease duration, which have confirmed higher numbers of circulating Treg cells in patients with long-standing disease [35, 39]. Moreover, in established disease, where proinflammatory cytokines, including TNF $\alpha$, are present at high levels in PB and target organs, FoxP3 expression within the $\mathrm{CD} 4{ }^{+} \mathrm{CD} 25^{+}$cell population seems to be reduced, giving rise to the hypothesis that proinflammatory molecules play a role in inducing an abnormal Treg cell phenotype [37, 40].

A more accurate phenotypic characterization of the $\mathrm{CD} 4{ }^{+} \mathrm{CD} 25^{\text {high }}$ cell population in RA patients was subsequently performed by evaluating the coexpression of potential Treg cell markers other than FoxP3 with the aim of confirming their regulatory phenotype. In this setting, some studies have found high levels of GITR on the surface of CD4+CD25 high cells in the SF of RA patients [33-35]. However, its specificity as a Treg cell marker in humans is not yet well established, so these findings are still inconclusive. Moreover, CTLA-4 expression on the surface of CD4+CD25 high cells in the PB of RA patients has been found to be reduced by FACS analysis, and this can be explained by increased internalization of this molecule as shown by confocal microscopy. Following anti-TNF therapy, CTLA-4 expression on the cell surface was restored and this finding seems to corroborate the effects of circulating inflammatory cytokines on the Treg cell phenotype by modulating the turnover of specific markers [43]. In addition, low surface expression of CD127 has been proposed as a highly specific feature of Treg cells in normal subjects and in patients with other autoimmune diseases [44]. Its assessment in Treg cells of patients with RA, however, appears not to be so specific in this context, since effector $\mathrm{T}$ cells can also display low levels of CD127 and CD25. Thus, it has been suggested that only FoxP3 detection may be helpful in distinguishing Treg from RA effector cells [17].

Table 1 Phenotypic characterization of Treg cells in rheumatoid arthritis

\begin{tabular}{|c|c|c|c|c|c|c|c|}
\hline \multirow[t]{2}{*}{ Reference } & \multirow[t]{2}{*}{ No. of patients } & \multicolumn{2}{|c|}{$\begin{array}{c}\mathrm{CD4}^{+} \mathrm{CD25}^{+} \\
\text {cells }(\%)\end{array}$} & \multicolumn{2}{|c|}{$\begin{array}{l}\mathrm{CD}^{+} \mathrm{CD} 25^{\text {high }} \\
\text { cells }(\%)\end{array}$} & \multirow{2}{*}{$\begin{array}{r}\mathrm{CD4}^{+} \mathrm{CD}^{+} 5^{+} \\
\text {cells expressing } \\
\text { FoxP3 }(\%)\end{array}$} & \multirow{2}{*}{$\begin{array}{r}\mathrm{CD4}^{+} \mathrm{CD25}^{+} \\
\text {cells expressing } \\
\text { GITR }(\%)\end{array}$} \\
\hline & & PB & SF & PB & $\mathbf{S F}$ & & \\
\hline 33 & 27 & $=$ & $\uparrow$ & $=$ & $\uparrow$ & ND & $\uparrow$ in SF \\
\hline 34 & 79 & $\uparrow$ & $\uparrow$ & ND & ND & ND & ND \\
\hline 35 & 18 & $=$ & $\uparrow$ & $\downarrow$ & $\uparrow$ & $\uparrow$ in SF & $\uparrow$ in SF \\
\hline 36 & 60 & $=$ & $\uparrow$ & $=$ & $\uparrow$ & ND & ND \\
\hline 42 & 43 (early) & & ND & & ND & ND & ND \\
\hline 38 & 44 & ND & ND & ND & ND & $\downarrow$ in SF & ND \\
\hline 40 & 11 & $\downarrow$ & $\uparrow$ & $\downarrow$ & $\downarrow$ & $\downarrow$ & ND \\
\hline 41 & 75 & $=$ & ND & ND & ND & $=$ & ND \\
\hline 39 & 14 & ND & ND & ND & ND & ND & ND \\
\hline 37 & 99 & $\uparrow$ & ND & $\uparrow$ & ND & $\downarrow^{\mathrm{a}}$ & $\uparrow$ in $\mathrm{PB} \mathrm{CD} 4^{+} \mathrm{CD} 25^{\text {high }}$ \\
\hline
\end{tabular}

$\uparrow, \downarrow$ or $=$ : increased, decreased or equal as compared to normal controls; $N D$ not done. aAlso reduced in $\mathrm{CD} 25^{\text {high }}$ subset. 
Since phenotypic characterization does not allow a definite conclusion as to whether expanded $\mathrm{CD} 4{ }^{+} \mathrm{CD} 25^{\text {high }} \mathrm{T}$ cells in the SF are actually Treg, the most convincing evidence is undoubtedly provided by in vitro functional studies. Suppressive activity of $\mathrm{CD} 4{ }^{+} \mathrm{CD} 25^{\text {high }} \mathrm{T}$ cells in the SF has been confirmed in some studies by coculture with autologous effector $\mathrm{T}$ cells [33-39]. In contrast, some authors have demonstrated a reduced suppressive activity of Treg cells in PB from RA patients, that can be restored by adequate pharmacological therapy, as discussed in detail below (see Table 2).

Functional differences between SF and PB Treg cells may be due to the fact that the in vitro assays deal with single cells removed from the inflammatory context and therefore cultured in a cytokine-free environment. In this context, their suppressor function could be lost in a microenvironment, such as the RA synovium, where proinflammatory cytokines are abundant.

Taken together, these observations have led to different hypotheses regarding the meaning of paradoxical in vivo Treg cell expansion in the joints of RA patients. It has been suggested that it may reflect a compensatory mechanism aimed at counteracting the rheumatoid proinflammatory microenvironment. In other words, Treg cells may be affected by cytokines produced within the RA synovium, and thus lose their suppressive activity. In this context, the suppressor activity displayed by Treg cells from RA patients in vitro may indicate that the physiological function of these cells can be recovered in the absence of proinflammatory stimuli. This impaired Treg cell function may favour the recruitment of other Treg cells into the target organs in an attempt to control the inflammatory process. Additional evidence supporting this hypothesis has come from the assessment of the chemokine secretory pattern of cells accumulating in RA synovium and SF [45]. It has been shown, indeed, that most of the $\mathrm{CD} 4{ }^{+} \mathrm{CD} 25^{+}$cells expressing FoxP3 also express high levels of inflammation-related trafficking chemokine receptors, including CCR4, CCR5 and CXCR4, that have been proven to be involved in Treg cell trafficking.

\section{Influence of pharmacological therapies on Treg cells in $\mathbf{R A}$}

The observed Treg cell expansion in rheumatoid joints and their supposed functional impairment related to the

Table 2 Effect of TNFa blockers on Treg cell phenotype and function in rheumatoid arthritis

\begin{tabular}{|c|c|c|c|c|c|c|}
\hline \multirow[t]{3}{*}{ Reference } & \multirow[t]{3}{*}{ No. of patients } & \multirow[t]{3}{*}{ Drug } & \multicolumn{4}{|c|}{$\mathrm{CD4}^{+} \mathrm{CD25}^{\text {high }}(\%)$} \\
\hline & & & \multicolumn{2}{|c|}{ Phenotype } & \multicolumn{2}{|r|}{ Function } \\
\hline & & & Before $^{a}$ & After $^{b}$ & Before $^{a}$ & After ${ }^{b}$ \\
\hline 48 & 27 & Infliximab & ND & ND & $\begin{array}{r}\text { Normal suppressive activity } \\
\text { but no inhibition of } \\
\text { inflammatory cytokines }\end{array}$ & $\begin{array}{r}\text { Recovered ability to } \\
\text { inhibit inflammatory } \\
\text { cytokines }\end{array}$ \\
\hline 50 & 17 & Infliximab & $\downarrow$ & $\uparrow$ & $\begin{array}{r}\uparrow \text { apoptosis of } \\
\mathrm{CD} 4{ }^{+} \mathrm{CD} 25^{\text {high }} \mathrm{T} \text { cells }\end{array}$ & $\begin{array}{r}\downarrow \text { apoptosis of } \\
\mathrm{CD} 4^{+} \mathrm{CD} 25^{\text {high }} \mathrm{T} \text { cells }\end{array}$ \\
\hline 51 & 18 & Adalimumab & $\downarrow$ & $\uparrow$ & $\begin{array}{r}\downarrow \text { suppressive activity and } \uparrow \\
\text { apoptosis of } \\
\mathrm{CD} 4^{+} \mathrm{CD} 25^{\text {high }} \mathrm{T} \text { cells }\end{array}$ & $\begin{array}{r}\uparrow \text { suppressive activity } \\
\text { and } \downarrow \text { apoptosis of } \\
\mathrm{CD} 4^{+} \mathrm{CD} 25^{\text {high }} \mathrm{T} \text { cells }\end{array}$ \\
\hline 52 & 15 & Infliximab & ND & ND & $\begin{array}{l}\text { No suppressive activity } \\
\text { and reduced inhibition of } \\
\text { inflammatory cytokines }\end{array}$ & Recovered suppressive activity \\
\hline 53 & 10 & Adalimumab & $\uparrow$ & $\begin{array}{r}\text { Same } \\
\text { percentage } \\
\text { as before }\end{array}$ & ND & ND \\
\hline 49 & 31 & Infliximab & $\uparrow$ & $\begin{array}{r}\text { but with } \\
\text { different } \\
\text { phenotype }\end{array}$ & $\downarrow$ suppressive activity & $\uparrow$ suppressive activity \\
\hline
\end{tabular}

$N D$ not done.

${ }^{\text {aB }}$ aseline levels as compared to normal controls.

${ }^{b}$ As compared to levels before therapy. 
RA inflammatory environment, prompted an analysis of the effect of inhibition of proinflammatory cytokines by administration of pharmacological treatments.

The role of corticosteroids (CS) in downregulating proinflammatory cytokines, such as TNFa, is well established. Supporting evidence in this setting has come from studies aimed at evaluating the effect of CS therapy on Treg cells in asthma, in which inhaled CS were demonstrated to upregulate both $\mathrm{CD} 4{ }^{+} \mathrm{CD} 25^{\text {high }} \mathrm{T}$ cell numbers and intracellular FoxP3 expression in this cell subset [46]. A recent longitudinal study in RA patients assessed the potential effect of local CS injections in modulating the Treg cell phenotype and their percentages in RA synovium and SF [47]. Immunohistochemistry and flow cytometry confirmed the previously reported findings of increased numbers of $\mathrm{CD} 4{ }^{+} \mathrm{CD} 25^{+} \mathrm{T}$ cells in $\mathrm{SF}$ and also showed an expansion of this cell subset in synovial tissue. Moreover, an enhanced number of $\mathrm{CD} 4{ }^{+} \mathrm{CD} 25^{\text {low }} \mathrm{T}$ cells expressing FoxP3 was also observed in RA synovium. Interestingly, the analysis of synovial infiltrate after CS injection revealed a parallel reduction of total and FoxP3 $^{+} \mathrm{T}$ cells. This finding may suggest that $\mathrm{CD} 4{ }^{+} \mathrm{CD} 25^{\text {low }} \mathrm{T}$ cells are recruited as Treg cells from the $\mathrm{PB}$ and are expanded in the synovial tissue to help suppress local inflammation. Subsequently, they may undergo conversion into effector cells induced by inflammatory mediators and are thus recognized as pathogenic by CS [47].

The increasing use of biological agents in clinical practice in rheumatic diseases has provided researchers with an interesting substrate to investigate the effect of TNF blockade in modulating Treg cell activity. As summarized in Table 2, recent studies by Ehrenstein et al. represent a milestone in this field [48-50]. They showed that infliximab is able to restore the ability of PB Treg cells from RA patients to inhibit proinflammatory cytokine secretion, including $\mathrm{TNF} \alpha$, in in vitro culture supernatants [48]. They also argued that anti-TNF therapy may generate a new Treg cell population in RA patients by converting effector $\mathrm{T}$ cells into Treg cells following unknown processes. This hypothesis has been confirmed in further studies which have demonstrated the induction of an adaptative Treg cell subset able to exert a suppressive effect via TGF $\beta$ in a cohort of infliximabtreated RA patients [49].

Subsequently, the effect of other anti-TNF agents on Treg cells were also evaluated. In this setting, infliximab and adalimumab were shown to interfere with Treg function both counteracting Treg apoptosis and restoring their suppressive activity [50-53]. Preliminary data on the effect of IL-6 inhibitors on Treg cells in vivo in a murine model of inflammatory arthritis have recently been reported. However, data on IL- 6 blockade by the mono- clonal antibody tocilizumab on Treg cells in RA are not available yet [54].

\section{Conclusion}

The current knowledge of Treg cells in RA reveals a very complex scenario which takes place both in rheumatoid synovium and in PB. In RA target organs, Treg cells appear to be increased. However, inflammation is not extinguished despite the enhanced presence of this immunoregulatory $\mathrm{T}$ cell subset. Further studies are needed to assess if blockade of proinflammatory mediators from the rheumatoid synovial environment by biological therapy may be beneficial not only by suppressing the inflammatory process but also by enhancing Treg cell-mediated suppression.

Taken together, these findings strengthen the hypothesis that an increase in Treg cell function and/or number in RA synovium may be a challenging therapeutic target.

Conflict of interest statement The authors declare that they have no conflict of interest related to the publication of this article.

\section{References}

1. Vandenbark AA, Offner H (2008) Critical evaluation of regulatory $\mathrm{T}$ cells in autoimmunity: are the most potent regulatory specificities being ignored? Immunology 125:1-13

2. Dieckmann D, Bruett CH, Ploettner H et al (2002) Human CD4(+)CD25(+) regulatory, contact-dependent $\mathrm{T}$ cells induce interleukin 10-producing, contact-independent type 1-like regulatory T cells. J Exp Med 196:247-253

3. Lan RY, Ansari AA, Lian ZX et al (2005) Regulatory T cells: development, function and role in autoimmunity. Autoimmun Rev 4:351-363

4. Sakaguchi S, Sakaguchi N, Asano M et al (1995) Immunologic self-tolerance maintained by activated $\mathrm{T}$ cells expressing IL-2 receptor $\alpha$ chain (CD25), breakdown of a single mechanism of self tolerance causes various autoimmune disease. J Immunol 155:1151-1164

5. Dieckmann D, Plottner H, Berchtold S et al (2001) Ex vivo isolation and characterization of CD4(+)CD25(+) T cells with regulatory properties from human blood. J Exp Med 193:1303-1310

6. Berthelot JM, Maugars Y (2004) Role of suppressor T cells in the pathogenesis of autoimmune diseases (including rheumatoid arthritis). Facts and hypotheses. Joint Bone Spine 71:374-380

7. Sakaguchi S, Wing K, Yamaguchi T (2009) Dynamics of peripheral tolerance and immune regulation mediated by Treg. Eur $\mathrm{J}$ Immunol 39:2331-2336

8. Bluestone JA, Abbas AK (2003) Natural versus adaptative regulatory T cells. Nat Rev Immunol 3:253-257

9. Shevach EM (2009) Mechanisms of foxP3+ T regulatory cellmediated suppression. Immunity 30:636-645

10. Curotto de Lafaille MA, Lafaille JJ (2009) Natural and adaptative foxP3+ regulatory $\mathrm{T}$ cells: more of the same or a division of labor? Immunity 30:626-635

11. Nocentini G, Giunchi L, Ronchetti S et al (1997) A new member of the tumor necrosis factor/nerve growth factor receptor family 
inhibits T cell receptor-induced apoptosis. Proc Natl Acad Sci U S A 94:6216-6221

12. Klein S, Kretz CC, Krammer PH et al (2010) CD127(low/-) and FoxP3+ expression levels characterize different regulatory $\mathrm{T}$ cell populations in human peripheral blood. J Invest Dermatol 130:492-499

13. Chatila TA, Blaeser F, Ho N et al (2000) JM2, encoding a fork head-related protein, is mutated in X-linked autoimmunity-allergic disregulation syndrome. J Clin Invest 106:R75-R81

14. Gambineri E, Torgerson TR, Ochs HD (2003) Immune dysregulation, polyendocrinopathy, enteropathy, and X-linked inheritance (IPEX), a syndrome of systemic autoimmunity caused by mutations of FOXP3, a critical regulator of T-cell homeostasis. Curr Opin Rheum 15:430-435

15. Fontenot JD, Gavin MA, Rudensky AY (2003) FoxP3 programs the development and function of $\mathrm{CD} 4+\mathrm{CD} 25+$ regulatory $\mathrm{T}$ cells. Nat Immunol 4:330-336

16. Feuerer M, Hill JA, Mathis D et al (2009) FoxP3+ regulatory T cells: differentiation, specification, subphenotypes. Nat Immunol 10:689-695

17. Aerts NE, Dombrecht EJ, Ebo DJ et al (2008) Activated T cells complicate the identification of regulatory $\mathrm{T}$ cells in rheumatoid arthritis. Cell Immunol 251:109-115

18. Gerli R, Nocentini G, Alunno A et al (2009) Identification of regulatory $\mathrm{T}$ cells in systemic lupus erythematosus. Autoimmun Rev 8:426-430

19. Zhang B, Zhang X, Tang FL et al (2008) Clinical significance of increased CD4+CD25+FoxP3+ T cells in patients with new-onset systemic lupus erythematosus. Ann Rheum Dis 67:1037-1040

20. Miyara M, Amoura Z, Parizot C et al (2005) Global natural regulatory $\mathrm{T}$ cell depletion in active systemic lupus erythematosus. $\mathrm{J}$ Immunol 175:392-400

21. Gottenberg JE, Lavie F, Abbed K et al (2005) CD4+CD25high regulatory $\mathrm{T}$ cells are not impaired in patients with primary Sjögren's syndrome. J Autoimmun 24:235-242

22. Valencia X, Yarboro C, Illei G et al (2007) Deficient $\mathrm{CD} 4+\mathrm{CD} 25$ high regulatory $\mathrm{T}$ cell function in patients with active systemic lupus erythematosus. J Immunol 178:2579-2588

23. Mellor-Pita S, Citores MJ, Castejon R et al (2006) Decrease of regulatory $\mathrm{T}$ cells in patients with systemic lupus erythematosus. Ann Rheum Dis 65:553-554

24. Barath S, Aleksza M, Tarr T et al (2007) Measurement of natural $(\mathrm{CD} 4+\mathrm{CD} 25 \mathrm{high})$ and inducible $(\mathrm{CD} 4+\mathrm{IL}-10+)$ regulatory $\mathrm{T}$ cells in patients with systemic lupus erythematosus. Lupus 16:489-496

25. Crispin JC, Martinez A, Alcocer-Varela J (2003) Quantification of regulatory $\mathrm{T}$ cells in patients with systemic lupus erythematosus. J Autoimmun 21:273-276

26. Liu MF, Wang CR, Fung LL et al (2004) Decreased CD4+CD25+ $\mathrm{T}$ cells in peripheral blood of patients with systemic lupus erythematosus. Scand J Immunol 59:198-202

27. Kelchtermans H, De Klerck B, Mitera T et al (2005) Defective $\mathrm{CD} 4+\mathrm{CD} 25+$ regulatory $\mathrm{T}$ cell functioning in collagen induced arthritis: an important factor in pathogenesis, counter-regulated by endogenous IFN-gamma. Arthritis Res Ther 7:R402-R415

28. Morgan ME, Sutmuller RP, Witteveen HJ et al (2003) CD25+ cell depletion hastens the onset of severe disease in collagen-induced arthritis. Arthritis Rheum 48:1452-1460

29. Morgan ME, Flierman R, van Duivenvoorde LM et al (2005) Effective treatment of collagen-induced arthritis by adoptive transfer of $\mathrm{CD} 25+$ regulatory $\mathrm{T}$ cells. Arthritis Rheum 52:2212-2221

30. Cuzzocrea S, Ayroldi E, Di Paola R et al (2005) Role of glucocorticoid-induced TNF receptor family gene (GITR) in collageninduced arthritis. FASEB J 19:1253-1265

31. Toh ML, Miossec P (2007) The role of T cells in rheumatoid arthritis: new subsets and new targets. Curr Opin Rheum 19:284-288
32. van Roon JA, Bijlsma JW, Lafeber FP (2006) Diversity of regulatory $\mathrm{T}$ cells to control arthritis. Best Pract Res Clin Rheum 20:897-913

33. Cao D, Malmstrom V, Baecher-Allan C et al (2003) Isolation and functional characterization of regulatory CD25brightCD4+ T cells from target organ of patients with rheumatoid arthritis. Eur J Immunol 33:215-223

34. Van Amelsfort JM, Jacobs KM, Bijlsma JW et al (2004) $\mathrm{CD} 4+\mathrm{CD} 25+$ regulatory $\mathrm{T}$ cells in rheumatoid arthritis: differences in the presence, phenotype and function between peripheral blood and synovial fluid. Arthritis Rheum 50:2275-2285

35. Mottonen M, Heikkinen J, Mustonen L et al (2005) CD4+CD25+ $\mathrm{T}$ cells with phenotypic and functional characteristics of regulatory $\mathrm{T}$ cells are enriched in the synovial fluid of patients with rheumatoid arthritis. Clin Exp Immunol 140:360-367

36. Liu MF, Wang CR, Fung LL et al (2005) The presence of cytokine-suppressive $\mathrm{CD} 4+\mathrm{CD} 25+\mathrm{T}$ cells in the peripheral blood and synovial fluid of patients with rheumatoid arthritis. Scand $\mathrm{J}$ Immunol 62:312-317

37. Han GM, O'Neil-Andersen NJ, Zurier RB et al (2008) $\mathrm{CD} 4+\mathrm{CD} 25$ high $\mathrm{T}$ cell numbers are enriched in the peripheral blood of patients with rheumatoid arthritis. Cell Immunol 253:92-101

38. Behrens F, Himsel A, Rehart S et al (2007) Imbalance in distribution of functional autologous regulatory $\mathrm{T}$ cells in rheumatoid arthritis. Ann Rheum Dis 66:1151-1156

39. van Amelsfort JM, van Roon JA, Noordegraaf M et al (2007) Proinflammatory mediator-induced reversal of $\mathrm{CD} 4+\mathrm{CD} 25+$ regulatory $\mathrm{T}$ cell-mediated suppression in rheumatoid arthritis. Arthritis Rheum 56:732-742

40. Jiao Z, Wang W, Li J et al (2007) Accumulation of FoxP3-expressing CD4+CD25+ $\mathrm{T}$ cells with distinct chemokine receptors in synovial fluid of patients with active rheumatoid arthritis. Scand J Rheumatol 36:428-433

41. Lin SC, Chen KH, Lin CH et al (2007) The quantitative analysis of peripheral blood FoxP3-expressing $\mathrm{T}$ cells in systemic lupus erythematosus and rheumatoid arthritis patients. Eur J Clin Invest 37:987-996

42. Lawson CA, Brown AK, Bejarano V et al (2006) Early rheumatoid arthritis is associated with a deficit in the CD4+CD25high regulatory $\mathrm{T}$ cell population in peripheral blood. Rheumatology 45:1210-1217

43. Flores-Borja F, Jury EC, Mauri C et al (2008) Defects in CTLA4 are associated with abnormal regulatory $\mathrm{T}$ cell function in rheumatoid arthritis. Proc Natl Acad Sci U S A 105:19395-19400

44. Venigalla RK, Tretter T, Krienke $S$ et al (2008) Reduced CD4+CD25- $T$ cell sensitivity to the suppressive function of CD4+CD25highCD127-/low regulatory $\mathrm{T}$ cells in patients with active systemic lupus erythematosus. Arthritis Rheum 58:2120-2130

45. Lim HW, Broxmeyer HE, Kim CH (2006) Regulation of trafficking receptor expression in human forkhead box P3+ regulatory T cells. J Immunol 177:840-851

46. Karagiannidis C, Akdis M, Holopainen P et al (2004) Glucocorticoids upregulate FOXP3 expression and regulatory $\mathrm{T}$ cells in asthma. J Allergy Clin Immunol 114:1425-1433

47. Raghavan S, Cao D, Widhe M et al (2009) FoxP3 expression in blood, synovial fluid and synovial tissue during inflammatory arthritis and intra-articular corticosteroid treatment. Ann Rheum Dis 68:1908-1915

48. Ehrenstein MR, Evans JG, Singh A et al (2004) Compromised function of regulatory $\mathrm{T}$ cells in rheumatoid arthritis and reversal by anti-TNF therapy. J Exp Med 200:277-285

49. Nadkarni S, Mauri C, Ehrenstein MR (2007) Anti-TNF $\alpha$ therapy induces a distinct regulatory $\mathrm{T}$ cell population in patients with rheumatoid arthritis via TGF $\beta$. J Exp Med 204:33-39

50. Toubi E, Kessel A, Mahmoudov Z et al (2005) Increased spontaneous apoptosis of $\mathrm{CD} 4+\mathrm{CD} 25+\mathrm{T}$ cells in patients with active 
rheumatoid arthritis is reduced by infliximab. Ann N Y Acad Sci 1051:506-514

51. Vigna-Perez M, Abud-Mendoza C, Alvarado Sanchez B et al (2005) Immune effects of therapy with adalimumab in patients with rheumatoid arthritis. Clin Exp Immunol 141:372-380

52. Valencia X, Stephens J, Goldbach-Mansky R et al (2006) TNF downmodulates the function of human CD4+CD25hi T-regulatory cells. Blood 106:253-261
53. Dombrecht EJ, Aerts NE, Schuerwegh AJ et al (2006) Influence of anti-tumor necrosis factor therapy (Adalimumab) on regulatory $\mathrm{T}$ cells and dendritic cells in rheumatoid arthritis. Clin Exp Rheumatol 24:31-37

54. Yoshida H, Hashizume M, Suzuki M et al (2010) Anti-IL-6 receptor antibody suppressed $\mathrm{T}$ cell activation by inhibiting IL-2 production and inducing regulatory $\mathrm{T}$ cells. Eur J Pharmacol (in press) 